\begin{tabular}{|c|c|c|}
\hline & Int.J.Curr.Microbiol.App.Sci (2016) 5(11): $432-441$ & \\
\hline & International Journal of Current Microbiology and Applied Sciences & 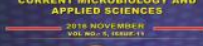 \\
\hline & ISSN: 2319-7706 Volume 5 Number 11 (2016) pp. 432-441 & \\
\hline $\begin{array}{l}\text { EXCELLENT } \\
\text { PUBLISHERS }\end{array}$ & & (1) \\
\hline
\end{tabular}

Original Research Article

http://dx.doi.org/10.20546/ijcmas.2016.511.050

\title{
Implementation Probiotics Cellulolitic B-7 Bacteria (Isolation from Buffalo Rumen) into Rations on the Performance, Abdominal Fat and Serum Cholesterol of Duck
}

\author{
Eny Puspani*, Desak Putu Mas Ari Candrawati and Dan I.G.N.G. Bidura \\ Faculty of Animal Science, Udayana University, Denpasar, Bali, Indonesia \\ J1. PB. Soedirman, Denpasar, Bali-Indonesia \\ *Corresponding author
}

\section{Keywords \\ Probiotics, buffalo rumen, performance, cholesterol, abdominal-fat, duck.}

\section{Article Info}

Accepted:

23 October 2016

Available Online:

10 November 2016

\section{A B S T R A C T}

This research aims to study the influence of cellulolitic B-7 bacterial isolates rumen of buffalo as a source of probiotics on the performances, abdominal fat, and cholesterol serum of a male Bali duck. A total of 240 male bali ducks were randomized in a completely randomized design (CRD) with four treatments and six replications. Treatment is attempted is the ducks that were given rations without supplementation of probiotic cultures cellulolitic as control (A); ration with $0.20 \%$ (B); $0.40 \%$; and $0.60 \%$ probiotic cultures selulolityc B-7, resvectively. The isolate has passed the test and has been considered as potential probiotic according to our previous study (Bidura et al., 2014). The results showed that the ducks were given rations containing probiotics result in weight gain and feed efficiency significantly $(\mathrm{P}<0.05)$ better than the control. However, administration of probiotics through diet significantly $(\mathrm{P}<0.05)$ can reduce abdominal fat weight and serum kolseterol in ducks. From these results it can be concluded that supplementation of $0.20 \%$ to $0.60 \%$ probiotic cellulolitic B-7 bacteria were isolated from the rumen of buffalo in the ration can significantly improve live weight gains and feed efficiency of Bali duck. In contrast, significantly reduced abdominal-fat weight and serum cholesterol of ducks.

\section{Introduction}

Public attention to the fat and cholesterol become greater, especially after it emerged that the consumption of fat/cholesterol excess will affect health. Not only to the increase in coronary heart disease, but lately informed also against cancer, diabetes, and high blood pressure (Santoso and Sartini, 2001). It was also reported that accumulation of high fat in the stomach and viscera may reduce the benefits of post- harvest plant and improve wastewater treatment problem. Therefore, it is very helpful if it can reduce cholesterol and abdominal fat chicken with biotechnology utilizing probiotics.

The use of antibiotics to stimulate the growth of poultry has been banned in European and American countries (Ahmad, 2006). Therefore, nutritionists and livestock 
production attracted to compounds that can serve as a substitute for antibiotics. Probiotics is one approach that has the potential to replace antibiotics. Probiotics are live microorganisms which when administered through the digestive tract, have a positive impact on the health and production of the host. According to Putra et al., (2015), the addition of probiotics in the ration is expected to enhance the role of normal flora in the digestive tract of cattle to produce exogenous enzymes, such as amylase, protease, and lipase which can enhance the activity of endogenous enzymes to hydrolyze feed nutrients.

Probiotics contain beneficial bacteria species that is normally found in the intestinal tract. Studies show that consumption of certain probiotic strains, particularly Lactobacillus can alter the intestinal microflora to produce a beneficial effect. Most commercially available strains of Lactobacilli and Bifidobacteria species are generally considered safe and can be very helpful in the treatment of pediatric diarrhea. However, the clinical benefits of probiotic therapy depends on many factors, such as the type of bacteria, the accuracy of the dose, method of delivery, and other environmental factors underlying (Dinkçi et al., 2006).

Based on this, interesting to note is the use of cellulolytic microbes from buffalo rumen fluid as the fiber degrading in the gastro intestinal tract of poultry. This is possible because the buffalo rumen fluid microbes turns out to have the highest cellulolytic activity compared with other livestock cellulolytic microbes. According to Sudirman (2004) in addition to determining the source of the microbial digestion of fiber activity, is also determined by the exact microbial inoculum dose, type, and microbial populations were used. Provision of microbial cultures from buffalo rumen fluid to the ducks is expected to lead to a synergistic effect between species of buffalo rumen microbes with microbes of duck in digestive tract, which can lead to the ability to digest fiber.

Some of the results of the preliminary study on the use of probiotics in the ration was able to improve performance, digestibility, efficiency ration, and lowering the amount of abdominal fat and cholesterol body poultry (Bidura et al., 2012; Bidura et al., 2014; Bidura et al., 2016; Candrawati et al., 2014). According to Siti et al., (2016), supplementation of 0.40 to $0.60 \%$ cellulolytic bacteria culture isolated from the rumen of buffalo in the tofu-based rations can improve the performance, carcass weight, carcass percentage, and the percentage of breast meat of ducks. In contrast, significantly reduced the amount of abdominal fat, blood serum cholesterol levels, and the concentration of $\mathrm{N}-\mathrm{NH} 3$ in excreta of duck. Furthermore, the beneficial effect of supplementation of probiotics has also been reported by some research workers such as Yousefi and Karkoodi (2007), Yamada and Sgarbieri (2005), Queiroz et al., (2004) and Roni et al., (2014), Ghasemi et al., (2006), Mohiti et al., (2007). On the other hand, some authors such as Ayanwale et al., (2006) reported that probiotics supplementation on diet has no effect on performances.

Based on the description above research aimed to study the effect of supplementation cellulolytic bacteria selected from the rumen of buffalo into diets to improve performance and reduce levels of cholesterol of ducks.

\section{Materials and Methods}

\section{Animals and experimental design}

A total number of 240 male Bali duckling (Anas sp) at 2 weeks of age and with 
homogenous body weight were randomly divided and caged in 24 separate pens with 10 birds in each pen. Prior to introduction of the experimental birds, the pens were thoroughly cleaned and disinfected. During the course of experiment, the birds were maintained under standard management condition for 42 days (6 weeks). For the purpose of examination of their carcasses and cholesterol concentration, 30 birds from each treatment group were randomly sampled.

A completely randomized design (CRD) was employed in the current experiment. Four treatment groups were assigned depending on their diets. All animals were fed an isonitrogenic and isocaloric ration in the form of mash and has been prepared in a such that meet the birds requirement to NRC (1984). Various levels of cellulolitic B-7 bacteria isolates obtained from rumen of buffalo as a source of probiotics slaughtered at the local abattoir, were supplemented on the diet. The difference in its level of application determined the four different experimental groups assigned. In the current experiment, addition of $0.0 \%(0 \mathrm{~g} / \mathrm{kg}$ diet $)$; $0.20 \%$ (2.0 g/kg diet); $0.40 \%$ (4.0 g/kg diet); and $0.60 \%(6.0 \mathrm{~g} / \mathrm{kg}$ diet $)$ were considered as the Treatment A (control), Treatment B, Treatment $\mathrm{C}$, and Treatment $\mathrm{D}$, respectively. Each group consisted of 6 replications with 10 birds in each replicate; therefore, the total number of experimental animals used in the current study was 240 birds. They were all provided with feed and drinking water $a d$ libitum.

The probiotic used in the current study was cellulolitic B-7 bacteria isolates, which was isolated from from rumen of buffalo slaughtered at the local abattoir. The isolate has passed the test and has been considered as potential probiotic according to our previous study (Bidura et al., 2014).

\section{Body Composition}

At the end of the experiment (56 days of age) 30 birds from each treatment were selected and slaughtered for determination of body composition. The leg and breast meats were separated from the carcass. The parts of the body fat are: pad-fat (separated from the organs of the abdominal viscera to the skin), mecenteric-fat (linkage separated from the intestine), vernticulus-fat, and abdominal-fat (a combination of fat-pad, ventriculus-fat, and mecenteric-fat).

\section{Total serum cholesterol}

For analysis of total serum cholesterol, two $\mathrm{ml}$ of blood was taken from the jugular vein of each duckling and centrifuged at 3000 rpm for 20 minutes. The blood samples were allowed to clot in a sample bottle and serum harvested was used to determine the total serum cholesterol content with the aid of a analyzed by the method of LibermanBurchard (1980).

\section{Statistical analysis}

Data collected was subjected to Analysis of Variance and if significant different among the treatment group was noted, they were then underwent further statistical analysis following Duncan's Multiple Range Test (Steel and Torrie, 1989).

\section{Results and Discussion}

Results of the current study are presented in Table 1. It can be noted that supplementation on diet of various level of the probiotic ranging from $0.20 \%$ to $0.60 \%$ resulted in a significant $(\mathrm{P}<0.05)$ increase in live weight gains. Moreover, the supplementation of $0.20-0.60 \%$ of cellulolytic $B-7$ bacteria culture significantly $(\mathrm{P}<0.05)$ increased feed efficiencies. 
However, no significant different $(\mathrm{P}>0.05)$ in feed consumption was noted.

At the end of the experiment (at eight weeks of age), showed live weight gains during the six weeks of observation ducks that were given rations without supplementation of probiotic cellulolytic B-7 bacteris isolated from rumen buffalo as a control is 1058.75 g/birds (Table 1). Supplementation cellulolytic B-7 bacteria at the levels: $0: 20 \% ; 0: 40 \%$, and $0.60 \%$ in the ration, respectively were $18.48 \%$; $19.56 \%$; and $22.91 \%$ higher than controls and were statistically significantly different $(\mathrm{P}<0.05)$.

The mean value of the feed conversion ratio (feed consumption: weight gain) on ducks control is 5.45 (Table 1). The mean value of FCR ducks received treatment $\mathrm{B}, \mathrm{C}$, and $\mathrm{D}$, respectively, were: $14.13 \%$; $14.50 \%$; and $16.88 \%(\mathrm{P}<0.05)$ lower than the control. The results showed that the average amount of abdominal fat in ducks control was $2.85 \%$ body weight. The average amount of abdominal fat ducks received treatment $\mathrm{B}$, $\mathrm{C}$, and D respectively, are: $17.54 \% ; 16.14 \%$; and $18.60 \%(\mathrm{P}<0.05)$ lower than the control. Total cholesterol levels in the blood serum of control duck was $185.64 \mathrm{mg} \mathrm{dl}$ (Table 1). Mean serum cholesterol levels of ducks treatment $\mathrm{B}, \mathrm{C}$, and $\mathrm{D}$, respectively, were: $11.22 \% ; 10.61 \%$; and $12.70 \% \quad(\mathrm{P}<0.05)$ lower than the control.

The results showed that supplementation of 0.40 to $0.60 \%$ bacterial culture isolates cellulolitic B-7 were isolated from the rumen of buffalo in the diet can increase the performance of ducks (live weight gains and feed efficiency). Because culture isolate cellulolytic rumen of buffalo that have passed the test as an agent of probiotics and have activity cellulolitic or has an activity of CMC-ase (Bidura et al., 2014) in the digestive tract is able to improve the digestibility of the feed, in particular feed fiber roughness height, into compounds simpler so more easily absorbed by the body ducks.

Feed efficiencies and LWGs in bird offered probiotic group are higher than control groups. This may be caused by the fact that probiotics contain species of beneficial bacteria that are commonly found in the intestinal tract. Most commercially available strains of Lactobacilli and Bifidobacteria species are generally considered safe and may be especially helpful in treatment of diarrheal illnesses. However, clinical benefit of probiotic therapy is dependent on numerous factors such as type of bacteria, dosing regimen, delivery method, and other underlying host factors (Dinkçi et al., 2006). The use of cultures such as Saccharomyces cerevisiae can improve weight gain, as a result of the response to increased dry matter intake. Especially, Saccharomyces cerevisiae, have been used in animal diets for several decades and are considered sources high quality proteins and B-complex vitamins, selenium and zince (Queiroz et al., 2004).

Moreover, Piao et al. (1999) noted that the use of $0.10 \%$ yeast (Saccharomyces serevisiae) in the ration significantly increased weight gain, feed efficiency and nutrient digestibility as well as reduce the amount of $\mathrm{N}$ and $\mathrm{P}$ secreted in the feces. Study in ducks by Bidura et al. (2012) also confirmed the previous findings; supplementation of $0.10 \%$ yeast culture led to an improvement in feed intake, feed conversion ratio, and weight gain. Such a finding is further supported by results of Umiarti et al., (2014) who found that the use of $0.10 \%$ to $0.30 \%$ Saccharomyces spp culture significantly improved live weight gains and feed efficiency. More positive effects of yeast supplementation were 
reported by Mulyono et al., (2009), Wu et al., (2005) and Huang et al., (2004). Santin et al. (2001) found that supplementation of feed with S.cerevisiae cell wall $(0.2 \%)$ improved broiler body weight. Many studies indicate that the addition of the culture of probiotic or enzyme in high feed content NSP can significantly reduce the viscosity of the digestive tract (intestinal viscosity), increase energy and protein retention (Wang et al., 2004; Bidura et al., 2012; Chen et al., 2005).

According to Stanley et al., (1993), which found that broiler chickens were given probiotics $0.10 \%$ can significantly improve weight gain and feed efficiency. Giving feed containing probiotics can stimulate the metabolism of poultry feed in the digestive process (Nurhayati, 2008). Probiotic microbes such as Aspergillus oryzae and Saccharomyces cerevisiae in the digestive tract of poultry at the level of $0.15 \%$ and $0.30 \%$ can increase the activity of amylolytic and proteolytic enzymes, thus increasing energy and digestibility of dietary protein termetabolis (Han et al., 1999).

Apparently, the role of culture isolate cellulolytic rumen of buffalo as a probiotic agent in the digestive tract of ducks effective at levels from 0.20 to $0.60 \%$ in the ration. Piao et al., (1999) reported that probiotic supplementation in the diet can markedly increase live weight gains, nutrient absorption, and the absorption of nitrogen and phosphorus. The results of this study are supported by Wu et al., (2005) and Huang et al., (2004) that Aspergillus xylanase supplementation in wheat bran-based ration can improve the performance of broiler chickens. The same thing was reported by Mulyono et al., (2009) that the addition of $1.0 \%$ S.cerevisiae $\left(9 \times 10^{9} \mathrm{cfu}\right)$ derived from baker's yeast in the basal ration of broiler chickens significantly increase the digestibility of dry matter, digestible protein, and protein efficiency ratio. Yi et al., (1996) reported that microbes in feed supplementation can memperbaiiki $\mathrm{N}$ retention in broiler and improve the digestibility of protein. It was also reported by Chen et al., (2005), that the addition of probiotic complex (L.acidophilus and S.cerivisae) in the basal diet can markedly increase the digestibility of dry matter feed.

Utama (2011), reported that the administration of probiotics (yeast Saccharomyces cerevisiae) in feed can improve the digestibility of protein and crude fiber components, such as cellulose and hemicellulose, since been overhauled in the form of simple monosaccharide. Chen et al., (2005) reported that the complex probiotic supplementation in the ration can markedly increase the digestibility of nutrients. Many studies indicate that the addition of culture probiotic or enzyme in high feed content NSP's can significantly reduce the viscosity of the digestive tract (intestinal viscosity), increase energy and protein retention (Wang et al., 2004; Bidura et al., 2012; Yi et al., 1996; Chen et al., 2005).

Supplementation of 0.20 to $0.60 \%$ bacterial culture isolates cellulolitic B-7 were isolated from the rumen of buffalo in the diet significantly reduced the amount of abdominal fat and blood cholesterol levels of ducks. These results are supported by Nurhayati (2008) that the use of the feed mixture fermented by Aspergillus niger at the level of $10-30 \%$ significantly reduced abdominal fat weight. Lactic acid bacteria in the digestive tract of poultry is able to utilize the energy derived from carbohydrates to lower the $\mathrm{pH}$ of the digestive tract to 4.5 resulting in the digestive tract becomes acidic. Acidic conditions causing lipase activity to be 
limited, so that the reduced fat digestion and subsequent synthesis of fat to decrease. Research on pigs conducted by Min (2006) reported that feeding fermented can reduce the fat content.

Supplementation of culture isolates B-7 cellulolytic bacteria isolated from the rumen of buffalo in the ration significantly reduced plasma cholesterol levels. According Ezema and Yeh (2015), probiotics may contribute to the regulation of serum cholesterol concentrations were carried out by deconjugated bile acids. Cholesterol is a precursor to the formation of bile acids and bile acid excretion when deconjugated enhanced by probiotic supplementation, the precursor molecule then be required to restore the formation of bile acids. The results of this study are supported by Park $e t$ al., (2008) and Sutarpa et al., (2011) reported that the use of probiotics in the diet can lower cholesterol levels in serum and chicken meat. Probiotic supplementation at a rate of $1.0 \mathrm{~g} / \mathrm{kg}$ ration can be recommended for optimum egg production and to reduce the concentration of cholesterol in serum and egg (Ezema and Eze, 2015).

Table.1 Implementation of Probiotics cellulolitic B-7 bacteria isolates of Rumen Buffalo in rations for Reducing abdominal-fat and Cholesterol serum of Ducks (aged 2-8 weeks)

\begin{tabular}{|c|c|c|c|c|c|}
\hline \multirow[t]{2}{*}{ Variable } & \multicolumn{4}{|c|}{$\begin{array}{l}\text { Supplemented of cellulolytic B-7 bacteria in } \\
\text { rations (\%) }\end{array}$} & \multirow[t]{2}{*}{ SEM $^{1)}$} \\
\hline & 0.00 & 0.20 & 0.40 & 0.60 & \\
\hline Live weight gains ( $\mathrm{g} / 6$ weeks) & $1058.75 b$ & $1254.42 \mathrm{a}$ & $1265.92 \mathrm{a}$ & $1301.32 \mathrm{a}$ & 52.056 \\
\hline Feed consumption ( $\mathrm{g} / 6$ weeks) & $5765.35 \mathrm{a}$ & $5869.83 \mathrm{a}$ & $5904.61 \mathrm{a}$ & $5895.74 \mathrm{a}$ & 78.457 \\
\hline Feed conversion ratio (feed/gains) & $5.45 \mathrm{a}$ & $4.68 \mathrm{~b}$ & $4.66 \mathrm{~b}$ & $4.53 \mathrm{~b}$ & 0.214 \\
\hline Abdominal fat ( $\%$ berat badan) & $2.85 \mathrm{a}$ & $2,35 b$ & $2.39 b$ & $2.32 \mathrm{~b}$ & 0.107 \\
\hline Cholesterol serum $(\mathrm{mg} / \mathrm{dl})$ & $185.64 a$ & $164.82 \mathrm{~b}$ & $165.95 \mathrm{~b}$ & $162.06 \mathrm{~b}$ & 5.038 \\
\hline
\end{tabular}

1. Standart Error of the treatments means

2. Means with different superscripts within raws are significantly different $(\mathrm{P}<0.05)$

Probiotic may contribute in the regulation of serum cholesterol concentrations conducted by deconjugated bile acids. As cholesterol is a precursor for bile acid formation and when deconjugated bile acids excretion is enhanced by probiotics supplementation, then more precursor molecules are needed for the recovery of bile acid formation (Ezema and Eze, 2015). Consequently, it may be expected that level of serum cholesterol decreases (Park et al., 2008; Sutarpa et al., 2011). Moreover, Klaver and Van Der Meer (1993) also suggested that co-precipitation with bile acids may be of importance in decreasing serum cholesterol concentrations. Ezema and Eze (2015) suggested, probiotic (S.cerevisiae) inclusion level of $1.0 \mathrm{~g} / \mathrm{kg}$ of layers mash is rekomanded for optimum hen-day egg performance and minimum serum and egg cholesterol content (Bidura et al., 2016).

DeSmet et al. (1998) reported that probiotics could contribute to the regulation of serum cholesterol concentration by deconjugated bile acids. Since the excretion of deconjugated bile acid is enhanced and cholesterol is it's precursor, more molecules 
are spent for recovery of bile acids (Ezema and Eze, 2015). As a result of increased synthesis of these acids, it is expected that the level of serum cholesterol will be reduced. That co-precipitation with bile acid might be of importance in decreasing serum cholesterol concentrattion.

In conclution, that supplementation of 0.20 to $0.60 \%$ cellulolytic B-7 bacteria culture isolated from the rumen of buffalo in rations can improve the performance of ducks. In contrast, significantly reduced the amount of abdominal fat and blood serum cholesterol levels of duck.

\section{Acknowledgements}

The authors would like to thank to staff of laboratory attendants at the Nutrition Laboratory, Udayana University for their assistance in chemical analysis of the samples. We also would like to deliver our appreciation to the Head of Research and Public Service Department and Rector of Udayana University, Denpasar for their support during the course of competition to obtain research fund.

\section{References}

Ahmad, I. 2006. Effect of probiotics on broilers performance. Int. Poult. Sci., 5: 593-597.

Ayanwale, B.A., M. Kpe and V.A. Ayanwale. 2006. The effect of supplementing Saccharomyces cerevisiae in the diets on egg laying and egg quality characteristics of pullets. Int. Poult. Sci., 5: 759-763.

Bidura, I.G.N.G., I.B.G. Partama, D.K.H. Putra and U. Santoso. 2016. Implementation on diet of Probiotic Saccharomyces spp.SB-6 isolated from colon of Bali cattle on egg production and egg cholesterol concentration of Lohmann brown laying hens. Int. J. Curr. Microbiol. App. Sci. 5 (4): 793-802. doi: http://dx.doi.org/ 10.20546/ijcmas.2016.504.091

Bidura, IGNG., I.B. Sudana, I.P. Suyadnya, I.G. Mahardika, I.G.L.Oka, I.B.Gaga Partama, and I.G.A.I. Aryani. 2012. The implementation of Saccharomyces spp.n-2 isolate culture (isolation from traditional yeast culture) for improving feed quality and performance of male Bali duckling. Agri. Sci. Res. J., 2 (9): 486-492.

Bidura, I.G.N.G., N.W. Siti and I. A. Putri Utami. 2014. Isolation of cellulolytic bacteria from rumen liquid of buffalo both as a probiotics properties and has CMC-ase activity to improve nutrient quality of soybean distillery byproduct as feed. Int. J. Pure \& Appl. Biosci., September Vol. 2 (5): 10-18

Candrawati, D.P.M.A., D.A. Warmadewi and I.G.N.G. Bidura. 2014. Implementation of Saccharomyces spp.S-7 isolate (Isolated from manure of Bali cattle) as a probiotics agent in diets on performance, blood serum cholesterol, and ammonia-N concentration of broiler excreta. Int. J. Res. Studies in Biosci., Vol. 2 (8): 6-16 Chen, Y. J., K. S. Son, B. J. Min, J. H. Cho, O. S. Kwon, and I. H. Kim. 2005. Effects of Dietary Probiotic on Growth Performance, Nutrients Digestibility, Blood Characteristics and Fecal Noxious Gas Content in Growing Pigs. Asian-Aust. J. Anim. Sci., Vol. 18 (10): 1464-1468

De Smet, I., L. Van Hoorde De Saaeyer, M. Van de Woeslyne and W. Verstraele. 1998. Cholesterol lowering in pig through enhanced bile salt hydrolase' activity. Br. J. Nutr., pp: 185-194

Dinkçi, N., G. Ünal, S. Akalin and S. Gönç. 2006. The Importance of Probiotics in 
Pediatrics. Pak. J. Nutrition, 5 (6): 608-611

Ezema, C. And D.C. Eze. 2015. Probiotic effect of yeast (Saccharomyces cerevisiae) on hen-day egg performance, serum and egg cholesterol in laying chickens. Pakistan J. Nutrition, 14 (1): 44-46

Ghasemi, H.A., A.M. Tahmasbi, G.H. Moghaddam, M.Mehri, S. Alijani E. Kashefi and A. Fasifi, 2006. The effect of phytase and Saccharomyces cerevisiae (SC47) supplementation on performance serum parameters, phosphorous and calcium retention of broiler chickens. Int. Poult. Sci., 5: $162-168$.

Han, S.W., K. W. Lee, B. D. Lee and C. G. Sung 1999. Effect of Feeding Aspergillus oryzae Culture on Fecal Microflora, Egg Qualities, and Nutrient Metabolizabilities in Laying Hens. AJAS, 12 (3): 417-421

Huang, M. K., Y. J. Choi, R. Houde, J. W. Lee, B. Lee, and X. Zhao. 2004. Effect of Lactobacilli and Acidophilic Fungus On The Production Performance and Immune Responses In Broiler Chickens. Poult. Sci., 88: 788-795

Lieberman, A. and R. Burchard, 1980. Enzimatic method to determined cholesterol. Engl. J. Med., 271: 915924.

Min, B. J. 2006. "Nutritional Value of Fermented Soy Protein (FSP) and Effect of FSP on Performance and Meat Quality of Pigs". (Ph.D. Thesis). Seoul, Korea: Department of Animal Resourches and Science.

Mohiti, Asli, M., S.A. Hosseini, H. Ltfollahian and F. Shariatmadari, 2007. Effect of probiotics, yeast, vitamin $\mathrm{C}$ supplements on performance and immune response of laying hen during high environmental temperature. Int. J. Poul. Sci., 6: 895900.

Mulyono, R. Murwani, dan F. Wahyono. 2009. Study Use of probiotic Saccharomyces cerevisiae as an Alternative to Antibiotics Additives to improve the usefulness of Protein and Energy in Broiler Chickens. $J$. Indonesian Trop. Anim. Agric. 34 (2): $145-151$

National Research Council. 1984. Nutrient Requirement Of Poultry. Washington, D. C.: National Academy Press.

Nurhayati 2008. Pengaruh Tingkat Penggunaan Campuran Bungkil Inti Sawit Dan Onggok yang Difermentasi dengan Aspergillus Niger dalam Pakan terhadap Bobot dan BagianBagian Karkas Broiler. Animal Production, Vol 10 (1): 55-59.

Park, Y.H., J.G. Kim, Y.W. Shin, H.S. Kim, Y.J. Kim, T. Chun and K.Y. Whang, 2008. Effects of Lactobacillus acidophilus 43121 and a mixture of Lactobacillus casei and Bifidobacterium longum on the serum cholesterol level and fecal sterol excretion in hypercholesterolemiainduced pigs. Biosc. Biotechnol. Biochem., 72: 595-600.

Piao, X. S., I. K. Han, J. H. Kim, W. T. Cho, Y. H. Kim, and C. Liang. 1999. Effects of Kemzyme, Phytase, and Yeast Supplementation on the Growth Performance and Pullution Reduction of Broiler Chicks. Asian-Aust. J. Anim. Sci., 12 (1): 36-41.

Putra, A.N., N.B.P. Utomo and Widanarni. 2015. Growth Performance of Tilapia (Oreochromis niloticus) Fed with Probiotic, Prebiotic and Synbiotic in Diet. Pakistan J. Nutrition, 14 (5): 263-268

Queiroz, R.C., A.F. Bergamaschine, J.F.P. Bastos, P.C. Santos and G.C. Lemos, 2004. Uso de produto a base de 
enzima e levedura na dieta de bovines: Digestibilidade dos nutrients e desempenho em confinamento. Rev. Brasil Zootech., 33: 1548-1556.

Roni, N. G. K., E. Puspani, Dan I G. N. G. Bidura. 2014. Efforts to Suppress Total Body Fat And Ammonia Gas excreta Ducks Management Through Feed Probiotics. The Magazine Scientific Ranch (Indonesia)18 (3): $119-124$

Santin, E., A. Maiorka, M. Macari, M. Grecco, J.C. Sanchez, T.M.Okada and A.M. Myasaka, 2001. Performance and intestinal mucosa development of broiler chickens fed diets containing Saccharomyces cerevisiae cell wall. $J$. Applied Poult. Res., 10: 236-244.

Santoso, U. and Sartini. 2001. Reduction of fat accumulation in broiler chickens by Sauropus androgynus (Katuk) leaf meal supplementation. Asian-Aust. J. Anim. Sci., 14:346-350

Siti, N.W., IGNG., Bidura, and I.A.P. Utami. 2016. The Effect of Supplementation Culture Cellulolytic Bacteria Isolated from the Rumen of Buffalo in the Tofu-Based Rations on the Performance and N-Nh3 Concentration in Excreta of Duck. $J$. Biol. Chem. Res., Vol. 33, No. 1. 214225

Stanley, V. G., R. Ojo, S. Woldesenbet, D. Hutchinson and L.F. Kubena. 1993. The Use of Saccharomyces sereviseae to Supress the Effects of Aflatoxicosis in Broiler Chicks. Poult. Sci., 72: 1867 $-1872$.

Steel, R.G. D. and J. H. Torrie. 1989. Principles and Procedures of Statistics. 2nd Ed. McGraw-Hill International Book Co., London.

Sutarpa, I. N. S., S. A. Lindawati, Y. Ramona, I. N. S. Miwada, I. N. T. Ariana, and M. Hartawan. 2011. The Effect of Lactic Acid Bacteria
Administration on The Performances, Total Bacteria in The Digestive Tract, and The Blood and Meat Cholesterol Content of Kampong Chickens. The $3 r d$ International Conference on Bioscience and Biotechnology. Maintaining World Prosperity trhough Biosciences, Biotechnology and Revegetation. 21-22 September 2011. Udayana University, Denpasar Bali, Indonesia. Udayana University Press. Pp. 110-112

Sudirman, I., 2004. Peranan Bakteri Asam Laktat dalam Kesehatan Hewan dan Peternakan, Pelatihan Mikrobiologi Dasar. Bogor: Fakultas Kedokteran Hewan IPB, Tanggal 26 April - 7 Mei 2004.

Umiarti, A.T., E. Puspani dan IGNG. Bidura. 2014. Influence of Saccharomyces spp culture level in the ration on the performances and the levels of ammonia gas in chicken excreta. The Magazine Scientific Ranch (Indonesia) 17 (3): 79-84

Utama, C.S.N. 2011. Potential of Probiotics rice bran. Poultry Indonesia.Vol VI, September: 78-80

Wang, J. F., Y. H. Zhu, D. F. Li, H. Jorgensen, and B. B. Jensen. 2004. The influence of different fiber and starch types on nutrient balance and energy metabolism in growing pigs. Asian-Aust. J. Anim. Sci., Vol. 17 (2): 263-270

Wu, Y., C. Lai, S. Qiao, L. Gong, W. Lu and D. Li. 2005. Properties of Aspergillus Xylanase and the Effects of Xylanase Supplementation In Wheat-Based Diets on Growth Performance and The Blood Biochemical Values In Broiler. Asian-Aust. J. Anim. Sci., Vol 18 (1): 66-74

Yamada, E.A. and V.C. Sgarbieri, 2005. Yeast (Saccharomyces cerevisiae) protein concentrate: Preparation, 
chemical composition and nutritional and functional properties. J. Agric. Food Chem., 53: 3931-3936.

Yi, Z., E.T. Kornegay and D. M. Denbow. 1996. Effect of microbial phytase on nitrogen and amino acid digestibility and nitrogen retention of turkey poults fed corn-soybean meal diets. Poultry
Sci., 75: 979-990.

Yousefi, M. and K. Karkoodi. 2007. Effect of probiotic thepax and Saccharomyces cerevisiae supplementation on performance and egg quality of laying hens. Int. $J$. Poult. Sci., 6: 52-54.

\section{How to cite this article:}

Eny Puspani, Desak Putu Mas Ari Candrawati and Dan I.G.N.G. Bidura. 2016. Implementation Probiotics Cellulolitic B-7 Bacteria (Isolation from Buffalo Rumen) into Rations on the Performance, Abdominal Fat and Serum Cholesterol of Duck. Int.J.Curr.Microbiol.App.Sci. 5(11): 432-441. doi: http://dx.doi.org/10.20546/ijcmas.2016.511.050 